Lars Slørdal (f. 1955) er spesialist i klinisk farmakologi, professor ved Institutt for laboratoriemedisin, barne- og kvinnesykdommer, Norges teknisk-naturvitenskapelige universitet og overlege ved Avdeling for klinisk farmakologi, St. Olavs hospital.

Ingen oppgitte interessekonflikter.

Olav Spigset (f. 1963) er spesialist i klinisk farmakologi og overlege ved Avdeling for klinisk farmakologi, St. Olavs hospital og professor ved Institutt for laboratoriemedisin, barne- og kvinnesykdommer, Norges teknisk-naturvitenskapelige universitet.

Ingen oppgitte interessekonflikter.

Hedda Rosland Garberg (f. 1986) er turnuslege ved Sykehuset Østfold Ingen oppgitte interessekonflikter.

Kristin Haugen Gladsø (f. 1988) er turnuslegevikar ved Sykehuset Østfold. Ingen oppgitte interessekonflikter.

Litteratur

1. Glads $\varnothing$ KH, Garberg HR, Spigset 0 et al. Skriftlig legemiddelreklame-fremdeles ikke til å stole på? Tidsskr Nor Legeforen 2014: 134: 1563-8.

2. Legemiddelforskriften. Oslo: Helse- og omsorgsdepartementet, 2009. to www.lovdata.no/cgi-wift/ldles?doc=\%2Fsf\%2Fsf\%2Fsf-20091218-1839.html (5.3.2013).

3. Bekelman JE, Li Y, Gross CP. Scope and impact of financial conflicts of interest in biomedical research: a systematic review. JAMA 2003. 289. 454-65.

4. Lexchin J, Bero LA, Djulbegovic B et al. Pharmaceutical industry sponsorship and research outcome and quality: systematic review. BMJ 2003; 326: 1167-70.

5. Lundh A, Sismondo S, Lexchin J et al. Industry sponsorship and research outcome. Cochrane Database Syst Rev 2012; 12: MR000033.

6. Slørdal L, Eggen AE, Rygnestad T. Interessekonflikter-en kunnskapsbasert tilnærming. Tidsskr Nor Legeforen 2012; 132: 1358-60.

7. Chew M, Brizzell C, Abbasi K et al. Medical journals and industry ties. BMJ 2014; 349 (nov28 4): g7197.

\section{Re: Nevroviten og psykiatri}

Finn Magnussen skriver godt og informativt om den betydelige utviklingen i nevrobiologien (1). Det er få temaer som interesserer meg mer enn denne utviklingen, og jeg ønsker å problematisere noe av det Magnussen skriver.

Magnussen skriver «om vi noensinne vil kunne forklare hvordan elektriske og biokjemiske reaksjoner i nevroner kan transdusere til subjektiv (...) opplevelse» (1). Forsker innen kognitiv vitenskap og filosof Daniel Dennett ville gjort Magnussen skyldig i hva han kaller «double transduction fallacy» (2). Vårt nervesystem koder forskjellige former for energi (lys, mekanisk, kjemisk osv.) ved å transdusere denne energien til forskjellige frekvenser av aksjonspotensialer. Magnussen, som så mange andre, tror at hjernen transduserer dette signalet en ekstra gang for å tilsynelatende gi opphav til et «show» for et indre vitne. Fra et evolusjonsmessig standpunkt er dette ytterst merkelig, og i sin bok Consciousness Explained forsøker Dennett å argumentere mot en slik tankegang (3). Dels fordi det er en potensielt falsk problemstilling og dels fordi den faller fort i filosofisk dualisme.

Magnussen skriver også at han håper fri vilje, kjærlighet og hat forblir fenomener i sin egen rett. Jeg har skrevet tidligere om fri vilje, og selve fenomenet er i beste fall problematisk å tro på (4). Dessuten, uten fri vilje følger en interessant implikasjon: kjærlighet forblir, men hat blir regelrett meningsløst. Du kan ikke noe for at du elsker noen, men du hater noen fordi de gjorde noe galt - en flott asymmetri fra naturens side spør du meg. En utbrodering av denne observasjonen krever mer enn én kommentar, men jeg henviser interesserte lesere til Sam Harris sin korte bok, Free will (5).

\section{Andreas Wahl Blomkvist}

andreas.wahl@gmail.com

Andreas Wahl Blomkvist (f. 1989) er medisinstudent ved Aalborg universitet og har verv i Forskningsutvalget for Den norske legeforening. Ingen oppgitte interessekonflikter.

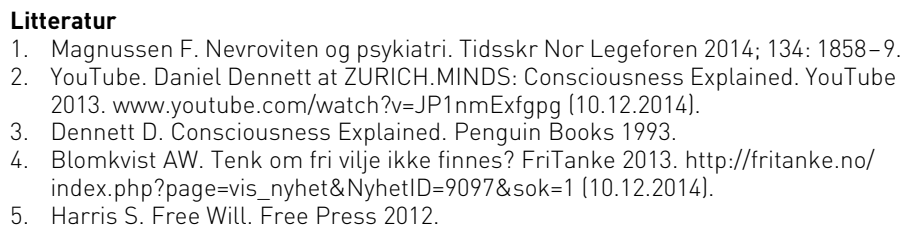

\section{F. Magnussen svarer:}

Takk for et interessant innspill. Problemet ligger kanskje $i$ at jeg har brukt ordet «transdusere», som jo betyr å omforme energi fra én fysisk form til en annen. Når det gjelder overgang fra fysisk energi til opplevelser og følelser, er det heller translasjon det dreier seg om, fra ett slags språk til et annet, selv om alt har et somatisk underlag. For en kliniker er poenget ved å «cerebralisere» tanker og følelser å finne biologiske markører og behandlingsmuligheter. Hva det ellers ville kunne innebære, tar oss inn i en helt annen debatt.

Dualisme er å tenke seg to selvstendige eksistens- og funksjonsnivåer. Men så mangfoldig er vår art blitt at vi har utviklet et mentalt plan og språk i tillegg til det fysiologiske, der vi forsøker å forstå oss selv og hverandre. Frihet og fri vilje er del av denne utviklingen, som til en viss grad har frigjort oss fra det nedarvete. Men det har selvsagt gitt oss nye problemer, der også filosofer og jurister er meningsberettigete. Om vi noensinne blir i stand til å forstå oss selv og vårt sinn i et nevrobiologisk språk, er det ikke gitt at det gir bedre liv eller bedre mennesker. Det kan bli svært nyttig for klinikere og pasienter. Men det mentale nivå var vel et skritt frem i menneskets utvikling?

Om kjærlighet er en mer opprinnelig emosjon enn hat er diskutabelt. Kjærlighet, med utspring i tilknytning («attachment») og tilhørighet, er også noe som må erfares og læres. Empati er ikke medfødt. Og hat er ikke bare noe vi lærer; jeg tror det har sitt utspring i det fremmede og farlige. Den benigne aggresjon, selvhevdelsen, kan i blant bli til malign aggresjon, ond, og der hører hatet hjemme.

\section{Finn Magnussen}

fi-mag@online.no

Finn Magnussen (f. 1925) er pensjonert lege og spesialist i psykiatri Ingen oppgitte interessekonflikter.

\section{Re: Nevroviten og psykiatri}

Jeg takker Magnussen for svar på min kommentar og for at han deler sine tanker rundt disse interessante temaene. Å bytte ut ordet transdusere med translasjon, og dermed frigjøre oss fra den fysiske betydningen av å transdusere noe, er nok mer korrekt når vi snakker om bevissthet. Hvorvidt man derfra velger emergentisme eller panpsykisme i forklaringen av bevissthet, er en helt annen debatt, som Magnussen nevner.

Den filosofiske dualismen vet jeg ikke helt om Magnussen bifaller, men han beskriver en slags fri vilje som «til en viss grad har frigjort oss fra det nedarvete». Jeg er av den oppfatning at nevrovitenskapelige studier har tilbakevist det tradisjonelle dualistiske synet på en årsakssammenheng mellom sinnet og hjernen. I en litteraturgjennomgang av nevrovitenskapelige studier om vilje skriver forfatteren i sin konklusjon: «Moderne nevrovitenskap avviser det tradisjonelle dualistiske synet på vilje som en årsakskjede fra det bevisste sinn eller sjel til hjerne og kropp. Snarere innebærer vilje et hjernenettverk som utfører en serie av komplekse, åpne avgjørelser mellom valgmuligheter» (min oversettelse) (1). fMRI studier kan også forutsi vilkårlige valg hele ti sekunder før personen er bevisst over sin egen avgjørelse (2). Disse studiene undergraver hele konseptet og er forenelig med den filosofiske posisjonen kalt inkompatibalisme, som vil si at fri vilje er inkompatibel med determinisme.

Jeg vil fortsatt utfordre Magnussen med at kjærlighet har et bedre grunnlag enn hat. Jeg innvilger at både kjærlighet og hat er naturlige følelser som er inngrodd $i$ vår psykologi. Likevel, man kan ikke 
hate noen med mindre du på en eller annen måte tror at de er årsaken til noe som er hatverdig. Uten fri vilje forsvinner dette grunnlaget. Det samme gjelder ikke kjærlighet.

\author{
Andreas Wahl Blomkvist \\ andreas.wahl@gmail.com \\ Andreas Wahl Blomkvist (f. 1989) er medisinstudent ved Aalborg Univer- \\ sitet. \\ Ingen oppgitte interessekonflikter.

\section{Litteratur} \\ 1. Haggard P. Human volition: towards a neuroscience of will. Nat Rev Neurosci \\ 2008; 9: 934-46. \\ 2. Soon CS, Brass M, Heinze HJ et al. Unconscious determinants of free decisions \\ in the human brain. Nat Neurosci 2008; 11: 543-5
}

\section{F. Magnussen svarer:}

Jeg ser det slik at menneskene har utviklet et mentalt operasjonsnivå, som har gitt oss et mer avansert handlingsrom via en bevissthet, som nå synes å høre til i ett eller flere cerebrale nettverk. Dette mentale nivået gir også rom for en opplevelse av ansvar for mer enn egen overlevelse, det vil si et sosialt liv. Dette ansvaret kan oppleves som valgfrihet eller som en mer eller mindre fri vilje. Nevrofysiologene burde tenke mer på hva det vil kunne føre til om vi skulle bli enda flinkere til å manipulere våre mentale liv på nevronalt nivå. At klinikere vil kunne lindre, endre eller fjerne symptomer er en viktig, men likevel bare liten del av denne mulige fremtid. Jeg håper jo at menneskets videre utvikling av seg selv, sine barn og alles mentale helse, i retning av mindre sårbarhet og mer robust tilpasningsevne, vil skje på det mentale plan, der man kan ha et eiendomsog ansvarsforhold til det, og ikke bare et pasient-klientforhold.

\section{Finn Magnussen \\ fi-mag@online.no}

Finn Magnussen (f. 1925) er pensjonert lege og spesialist i psykiatri Ingen oppgitte interessekonflikter.

\section{Re: Mål for gode lærere}

Det var med interesse vi leste Petter Gjersviks «Fra redaktøren» (1) der han kommenterer gjeninnføring av karakterer ved medisinerstudiet i Oslo. I konklusjonen skriver han at det kunne innføres karakterer til lærerne med samme begrunnelse som for innføring av karakterer til studentene. Vi kunne ikke være mer enige.

Vi vil lede oppmerksomheten til vårt studiested Universitetet i Tromsø, Norges arktiske universitet (UiT), der foreleserne har vært evaluert siden oppstarten i 1973. I 1993 publiserte en av de undertegnede en studie som oppsummerte de første 11 medisinerkulls syn på viktigheten av å ha mulighet til å evaluere lærerne med tanke på tema, omfang og pedagogiske kvalifikasjoner (2). I disse første årene ble denne evalueringen sett på som viktig, da studieplanen var ny og det var ønske om dynamiske forbedringer. Fortsatt blir undervisningen og lærerne evaluert, selv om formen har forandret seg noe (3). Det har alltid vært satt av tid på timeplanen til denne evalueringen.

Fra vår egen erfaring som studenter var muligheten til å evaluere undervisningen meget viktig, og i hovedsak ble det gitt konstruktiv kritikk. Vår erfaring som forelesere er også positiv. Tilbakemelding virker alltid stimulerende og gir muligheter for ytterlig forbedring. Pedagogiske kurs for lærere vil ikke nødvendigvis gi gode lærere, det trengs også klare tilbakemeldinger for at vi skal bli bedre. Evaluering er derfor helt essensielt.

Ved Det helsevitenskapelige fakultet, UiT har det vært utdelt en undervisningspris siden 1980-tallet nettopp for å sette søkelyset på undervisningens kvalitet. For dem som er genuint interessert i å gi god undervisning, er prisen klart noe som man kan strekke seg mot. Det er vår erfaring som leger og forskere vi skal formidle videre til nye generasjoner. Omfang av undervisning, samt arbeid med å forbedre undervisningskvalitet, bør meritteres høyere enn det som ofte er tilfellet når man søker stillinger. Som Dali Lama sier: «Del av din kunnskap, da kan du oppnå å leve evig». (Share your knowledge. It is a way to achieve immortality) (4).

\section{Anne Tollan \\ annetollan@gmail.com \\ Maja-Lisa Løchen}

Anne Tollan (f. 1954) er gynekolog.

Ingen oppgitte interessekonflikter.

Maja-Lisa Løchen (f. 1954) er professor i forebyggende medisin, Institutt for samfunnsmedisin, UiT Norges arktiske universitet.

Litteratur

1. Gjersvik P. Mål for gode lærere. Tidsskr Nor Legeforen 2014; 134: 1447.

2. Tollan A, Magnus JH. Evalueringer og eksamener i medisinerstudiet i Troms $\varnothing$. Tidsskr Nor Legeforen 1993: 113: 33-5.

3. Håndbok for ledere ved legeutdanningen i Troms $\varnothing$. Det helsevitenskapelige fakultet, UiT Norges arktiske universitet 2014.

4. http://www.dalailamaquotes.org.

\section{Re: Er det overvekt eller vektfokus som er helseskadelig?}

Samdal \& Meland tar for seg et viktig tema når de diskuterer om det er overvekt eller vektfokus som er helseskadelig (1). Det er lett å være enig i påstanden om at stigmatisering av overvektige personer og vektfokus, spesielt hos barn og ungdom, er en uheldig utvikling. Det er god grunn til å påstå at helsemessige effekter av vektreduksjon og endret kosthold er overkommunisert i samfunnet, mens den anerkjent positive effekten av økt fysisk aktivitet ikke formidles tydelig nok.

Etter undertegnedes oppfatning er kroppsfikseringen vi opplever i dagens samfunn ikke et resultat av den vitenskapelige diskusjonen om en eventuell helseskadelig effekt av overvekt, men et uavhengig fenomen. Jeg er overasket over hvor lite nyansert Samdal \& Meland fremstiller dette i debattinnlegget. Forfatterne oppgir hele 28 referanser, men underslår at noen av studiene som siteres har blitt sterkt kritisert i fagmiljøet. Samdal \& Meland siterer i stor grad fra Campos og medarbeidere (2). Hele syv kommentarer, delvis i sterke ordelag, om denne artikkelen har blitt publisert i samme tidsskrift. Det har blant annet blitt satt spørsmålstegn ved Campos og noen av medarbeidernes faglige kvalifikasjoner (3). Det ble skrevet at Campos og medarbeidere har lest litteraturen selektivt og trukket feilaktige konklusjoner (4) og at det ikke hersker tvil om at overvekt medfører alvorlige helsemessige konsekvenser (5). I den store metaanalysen fra Flegal og medarbeidere (6) som siteres, konkluderes det med at personer med moderat overvekt (BMI 25-30) har en lavere mortalitet enn «normalvektige». Dessverre har studien så omfattende og alvorlige metodiske feil at konklusjonen med all sannsynlighet er feil (7).

Undertegnende vil ikke utmatte leserne med en detaljert gjennomgang av alle påstander som er fremsatt i Samdal \& Melands debattinnlegg. Jeg vil derimot oppfordre til vitenskapelig redelighet og kritisk diskusjon også i kommentarer og debattinnlegg i Tidsskriftet. Forfattere i vitenskapelige stillinger har et betydelig ansvar når de uttaler seg om temaer som ligger i grenseland mellom vitenskap og samfunnsdebatt.

\section{Alexander Wahba}

alexander.wahba@ntnu.no

Alexander Wahba (f. 1962) er overlege og professor ved NTNU. Ingen oppgitte interessekonflikter. 